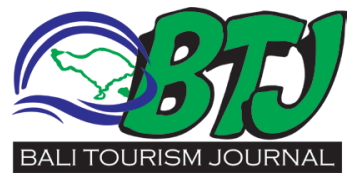

\title{
Panca Wali Krama 2019; through fire of Mount Agung Eruption to Overloaded Morgue crisis
}

\author{
Ida Ayu Adi Trisnawathi ${ }^{1}$
}

\section{ABSTRACT}

Balinese people hold Yadnya ceremony Panca Wali Krama every ten years. Panca means Five, represents five elements that compose the universe Panca Maha Bhuta, while Bali or Wali means offering or ceremony. In this year, the ritual was considered exceptional due to it took place twice, the first in Lempuyang Luhur Temple and the second in the largest temple in Bali, Besakih Temple. Hindu communities from all regions in Bali came to participate in the event, as their symbol of faith toward the God Almighty. This tenyear event took place for more than twenty days in Lempuyang Luhur and thirty-seven days in Besakih temple. While Panca Wali
Krama was taking place at Besakih, Mount Agung has been reported experiencing several hiccups on 9, 15 and 21 March 2019. Despite the eruption, the communities kept doing their prayer and service at the temple located on the slope of the volcano. Meanwhile, another crisis was faced by hospitals on the island, due to an announcement from the official to ban Ngaben ceremony until the Yadnya is over. As a result, Mortuary in several hospitals was reported overloaded. The official and Government hastily response to the overloaded problem, since according to Balinese Hindu believe, keeping the dead body stranded was considered defiling the area.
${ }^{1}$ Kopiku Roasters

Song.of.eternity@gmail.com

Editor:

Ida Bagus Ngurah Tri Pramana

Received: 2019-03-09

Accepted: 2019-03-21

Published: 2019-05-20

Keyword: Panca Wali Krama, Eruption, Mortuary

Cite This Article: Trisnawathi, I.A.A. Panca Wali Krama 2019; through fire of Mount Agung Eruption to Overloaded Morgue crisis. Bali Tourism Journal (BTJ)2019, 3 (1): 10-14

\section{BACKGROUND}

Balinese people hold Yadnya ceremony Panca Wali Krama every ten years. Panca means Five, represents five elements that compose the universe Panca Maha Bhuta, while Bali or Wali means offering or ceremony. If we discuss the Yadnya ceremony in Bali, mostly aims to invoke welfare, protection, and peace to the universe, including the Panca Wali krama ceremony. In this year, the ritual was considered exceptional due to it took place twice, the first in Lempuyang Luhur Temple and the second in the largest temple in Bali, Besakih Temple.

The ceremony in Lempuyang Temple was reheld after vacuuming for hundreds of years. Its guideline is written on the script of Brahmanda Rajapurana. ${ }^{1}$ The series of the ceremony began with Segara Kertih on 11 January 2019 on Amed Beach, carried by seven traditional villages in Abang District. Meanwhile, thirteen indigenous villages from twenty traditional villages in Abang Subdistrict carry out the peak of ceremony, on January $20^{\text {th }} \cdot 2$

Since Panca Wali Krama is a grand event, thus it is not held in every temple on the island. In addition to the Lempuyang Luhur Temple, the same ritual was held as well in Besakih Temple. Besakih Temple has philosophical and historical values as a temple of 'origins,' a sacred place which has the title of the oldest worship place and the highest CenterPoint for Balinese Hindus. ${ }^{3}$ Pura Besakih as a sacred place was explicitly stated in the letter addressed to the governor by the Regional Head dated August 31, 1951, Letter No. B / 6 / 5/14. One of the five points mentioned in the letter expressed that the temple Besakih, is classified into sacred temples because it is the first temple in Balinese history and every Galungan, people of Bali respects it by erecting Penjor on the right side of their house gate. ${ }^{4}$

The Panca Wali Krama series at Besakih Temple began on January 22, 2019. According to a circular from the PHDI Chairperson of Bali, Prof. Dr. I Gusti Ngurah Sudiana, there are several ceremonies before the main event, in the order according to Table 1.

On March 1 $1^{\text {st }}, 2019$, thousands of people, including the Governor and Vice Governor, Regent or Mayor in each district of Bali flocked at Besakih temple to attend the ritual of taking the God's holy relic at the Penataran Agung Besakih. This procession began around 3 PM Bali local time, although the rain poured over the temple, it did not lower the enthusiasm of the community. The procession was started by taking out the relic of deity Ida Bhatara Lingsir from its shrine. Bali Governor, I Wayan Koster and Vice Governor, Tjokorda Oka Artha Ardana Sukawati performed the duty to carry the relic. Continued by the relic 


\section{Table 1. Schedule of Panca Wali Krama series 2019 at Besakih Temple}

\begin{tabular}{|c|c|c|c|}
\hline No & Date & Time & Details \\
\hline 1 & Tuesday, 22 Januari 2019 & 10.00 Wita & matur piuning \& ngaku agem di Pura Agung Besakih \\
\hline 2 & Friday, 1 Februari 2019 & 10.00 Wita & nunas tirta panglukatan \& pemarisudha di Pura Dalem Puri Besakih \\
\hline \multirow[t]{3}{*}{3} & \multirow{3}{*}{$\begin{array}{l}\text { Wednesday, } 6 \text { Februari } \\
2019\end{array}$} & 08.00 Wita & ngaturang pemiyut at Pura Penataran Agung Besakih \\
\hline & & 09.00 Wita & $\begin{array}{l}\text { Council determining the best day for ritual, ngingsah nyangling, ngentegang \& ngunggahang } \\
\text { sunari }\end{array}$ \\
\hline & & 13.00 Wita & pengemit lan pangrajeg karya \\
\hline 4 & Friday, 15 Februari 2019 & 10.00 Wita & nyukat genah tawur, dan ngawit nanceb wewangunan at Bencingah Agung Besakih \\
\hline 5 & $\begin{array}{l}\text { Tuesday, } 19 \text { Februari } \\
2019\end{array}$ & 10.00 Wita & mamineh empehan \& makarya madu parka di Suci Pura Penataran Agung Besakih \\
\hline 6 & $\begin{array}{l}\text { Wednesday, } 27 \text { Februari } \\
2019\end{array}$ & & nuwur tirta to Mount Semeru, east java \& Mount Rinjani, Lombok \\
\hline \multirow[t]{2}{*}{7} & \multirow{2}{*}{$\begin{array}{l}\text { Thursday, } 28 \text { Februari } \\
2019\end{array}$} & \multirow[t]{2}{*}{10.00 Wita } & nuwur tirta to Mount Agung, \& Sad Kahyangan temples di Bali \\
\hline & & & bumi sudha, \& pemarisudha at Bencingah Agung Besakih \\
\hline 8 & Friday 1 Maret 2019 & $15.00 \mathrm{Wita}$ & nedunang pralingga Ida Betara di Pura Agung Besakih \\
\hline 9 & $\begin{array}{l}\text { Saturday, } 2 \text { Maret } 2019 \text { - } \\
\text { Monday, } 4 \text { Maret } 2019\end{array}$ & & melasti from Besakih to Watu Klotok beach, Klungkung \\
\hline \multirow[t]{2}{*}{10} & \multirow[t]{2}{*}{ Tuesday, 5 Maret 2019} & 10.00 Wita & mapepada tawur agung Panca Wali Krama \\
\hline & & 18.00 Wita & Memben at Bencingah Agung Besakih \\
\hline 11 & $\begin{array}{l}\text { Wednesday, } 6 \text { Maret } \\
2019\end{array}$ & 08.00 Wita & Ritual of Tawur Agung Panca Wali Krama \\
\hline 12 & Thursday, 7 Maret 2019 & 05.00 Wita & Penganyar, then a daybreak to commemorate Nyepi \\
\hline 13 & Friday, 8 Maret 2019 & 10.00 Wita & penganyar \\
\hline \multirow[t]{2}{*}{14} & \multirow[t]{2}{*}{ Saturday, 9 Maret 2019} & 10.00 Wita & penganyar \& mlaspas lan mapedagingan \\
\hline & & 14.00 Wita & Penglemek Tawur Agung Panca Wali Krama \\
\hline 15 & $\begin{array}{l}\text { Sunday, } 10 \text { Maret } 2019 \text { - } \\
\text { Monday } 18 \text { Maret } 2019 \\
\end{array}$ & & penganyar \\
\hline \multirow[t]{2}{*}{16} & \multirow[t]{2}{*}{ Tuesday, 19 Maret 2019} & 10.00 Wita & penganyar \& Mepepada Betara Turun Kabeh \\
\hline & & 18.00 Wita & memben \\
\hline 17 & $\begin{array}{l}\text { Wednesday, } 20 \text { Maret } \\
2019\end{array}$ & & The peak ceremony of Ida Betara Turun Kabeh \\
\hline 18 & $\begin{array}{l}\text { Thursday, } 21 \text { Maret } 2019 \\
\text { - Friday, } 22 \text { Maret } 2019\end{array}$ & & penganyar \\
\hline 19 & Saturday, 23 Maret 2019 & & penganyar lan pengelemek \\
\hline 20 & $\begin{array}{l}\text { Sunday, } 24 \text { Maret - } \\
\text { Monday, } 1 \text { April } 2019\end{array}$ & & penganyar \\
\hline 21 & Tuesday, 2 April 2019 & & penganyar and Rsi Bhojana \\
\hline 22 & $\begin{array}{l}\text { Wednesday, } 3 \text { April } \\
2019 \text { - Thursday, } 11 \\
\text { April } 2019\end{array}$ & & penganyar \\
\hline 23 & Friday, 12 April 2019 & 10.00 Wita & penganyar \\
\hline & & 15.00 Wita & nunas tirta panglebar, then penyineban \\
\hline
\end{tabular}

of Pura Gelap Besakih was carried by Klungkung Regent, I Nyoman Suwirta and Viceregent, Made Kasta then, the rest of the relics were carried by the other head of regencies in Bali. Then, All the sacred relics were displayed in the Penataran Agung. The procession has meant that all deities had gathered, to continue marching toward Watu Klotok beach. ${ }^{5}$

Before The sacred relics marched toward Watu klotok Beach, the entourage performed a prayer in Besakih Temple. After the prayer finished, the entourage began their travel, led by The Relics of Ida Bhatara Catur Lawa, consist of four deities Ida Bhatara Ratu Bagus Pande, Ratu Pasek, Ratu Bagus Penyarikan, and Ratu Dukuh Segening followed by other Relics. The entourage in the first day marched in a relay, covered distance about 27 kilometers to Watu Klotok beach, in Klungkung regency. 


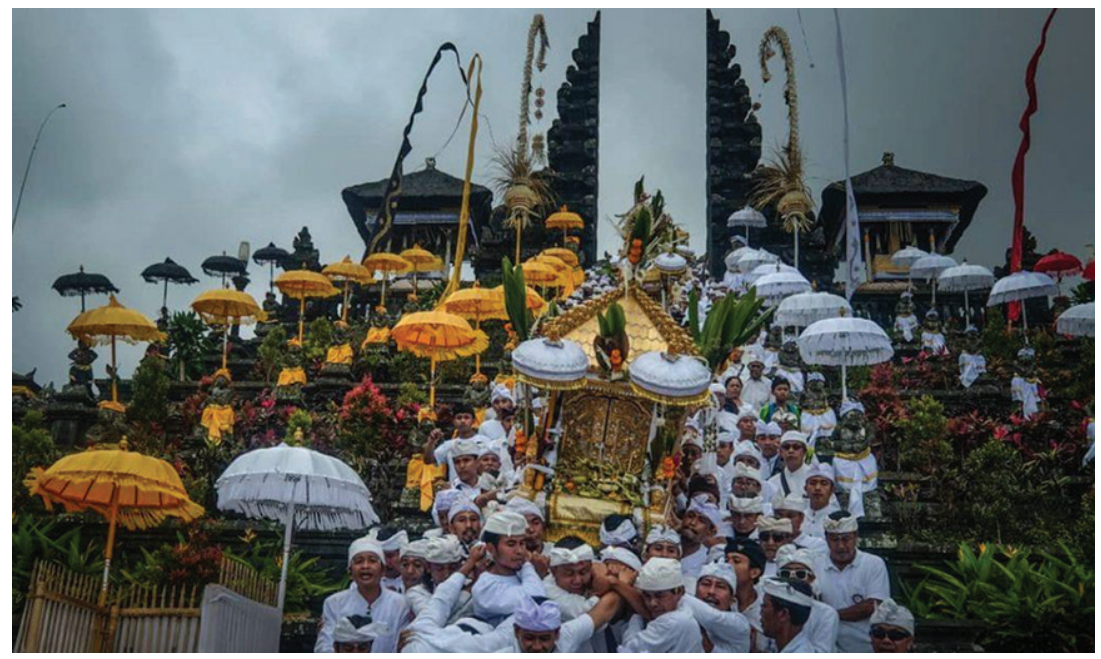

Figure. 1 After the prayer finished, the entourage began their travel, led by The Relics of Ida Bhatara Catur Lawa, consist of four deities Ida Bhatara Ratu Bagus Pande, Ratu Pasek, Ratu Bagus Penyarikan, and Ratu Dukuh Segening followed by other Relics. ${ }^{6}$

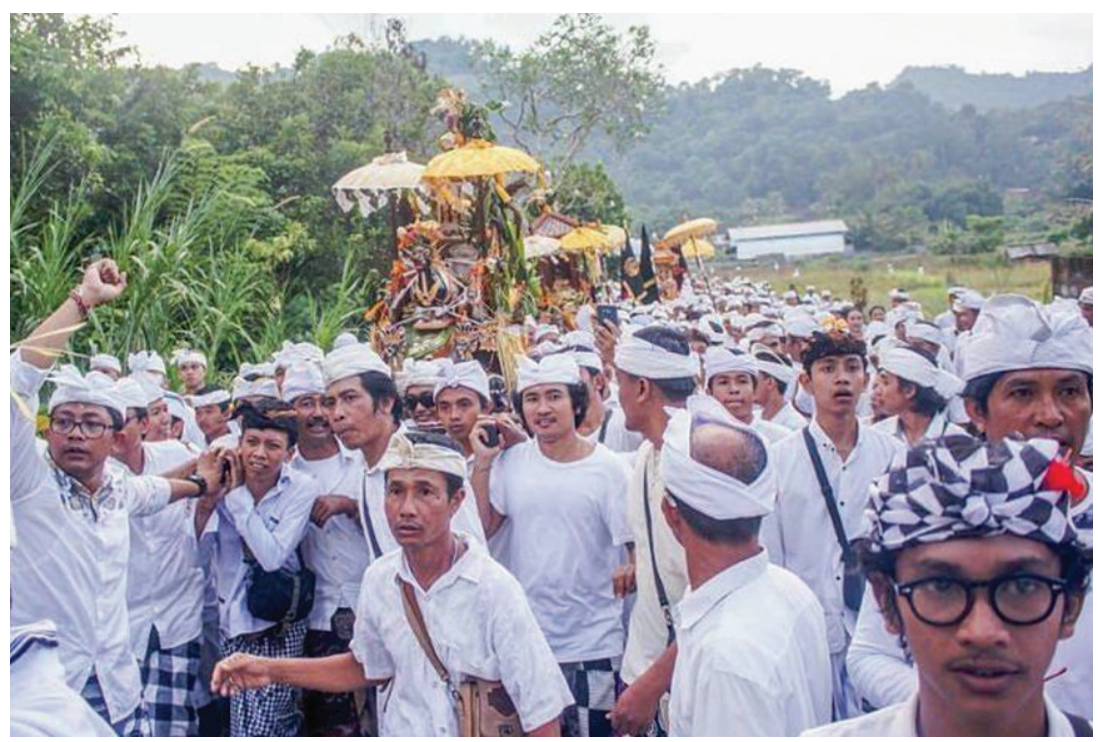

Figure 2. The sacred relics marched toward Watu klotok Beach

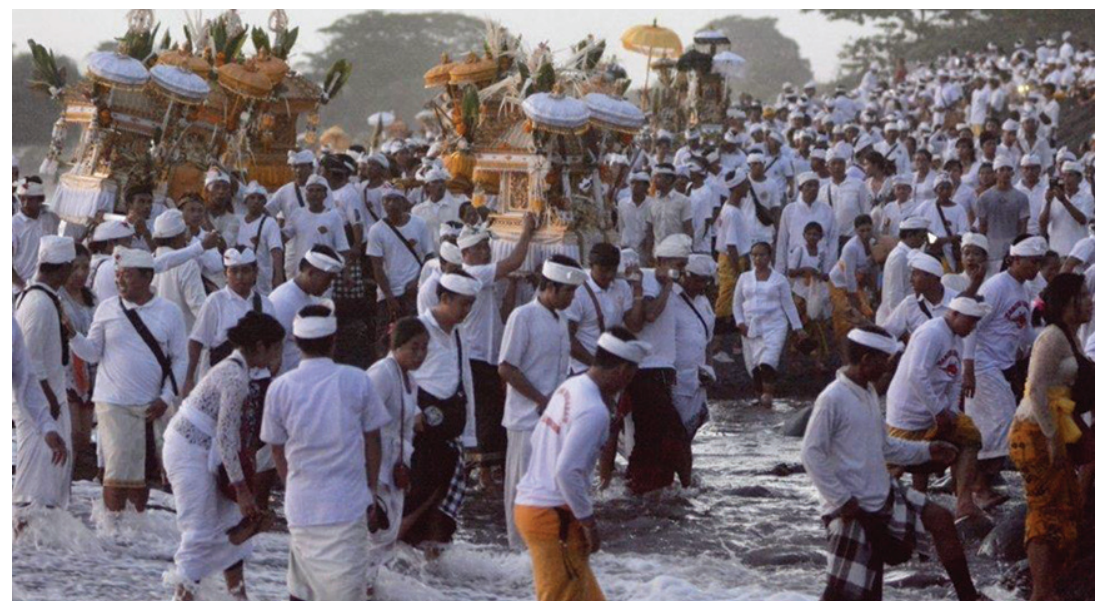

Figure 3. At Watu Klotok Beach ${ }^{8}$
After the Melasti procession at Watu Klotok, the entourage proceeded to Penataran Agung Klungkung Temple on Semeru Street, Semarapura. The party stayed overnight and continued the travel on the next day, on Sunday 03 February 2019. On the second day, the convoy visited several temples and villages: Puseh Temple in Tohjiwa Village, Paksebali Village, Lebu Village, and then the entourage stayed for overnight at Puseh Tebola Temple in Sidemen Village, the procession then continued on Monday $(03 / 04 / 2019)$. When the convoy returned at the Besakih Temple, the community then placed the relics on the altar. The procession was halted for three days due to preparation for Nyepi Day. The series of the ceremony lasted for a month and seven days, from January $22^{\text {nd }}$ until April $12^{\text {th }} 2019 .{ }^{9}$

Hundreds of Penjor were firmly stood in several villages in Karangasem and Klungkung areas. In this journey, the entourage passed twentynine Pakraman villages in the Karangasem and Klungkung areas within three days. Hundreds of thousands of people joined to relay the sacred relics entourage with a total travel distance reached 64.3 kilometers.

\section{MOUNT AGUNG ERUPTION}

During the Panca Wali Krama at Besakih temple, Mount Agung experienced several eruptions on 9, 15 and 21 March 2019. According to data of the Volcanology and Geological Disaster Mitigation Centre, Mount Agung erupted On Saturday 9 March at $12.47 \mathrm{pm}$ Bali local time. The Mountain watcher reported the eruption on Friday (3/15) occurred at 18:27. The ash column height around 1,000 meters above the peak, with eruption duration about 1 minute 23 seconds. The eruption also occurred on Thursday morning (3/21) at 1:18 p.m. The community who come to the Besakih temple, which is located on the slope of the mountain, could clearly see the eruptions. Despite experiencing few quakes and eruptions, the official kept the mountain status on level III (Standby). According to the Head committee of Panca Wali Krama, Jro mangku Widiartha, the eruption did not interfere with the ceremony procession.

Head of the observer Post in Rendang district, I Dewa Made Mertayasa, said that there is a possibility that Gunung Agung might erupt, due to its recent activities. However, the eruption would be small in intensity. Therefore, the official prohibited residents not to carry out any activities within a radius of 4 kilometers from the crater. Meanwhile, Chairperson of the Committee for Panca Wali Krama, Jro Mangku Widiartha said that the Mount Agung eruption did not disturb the ritual. The 


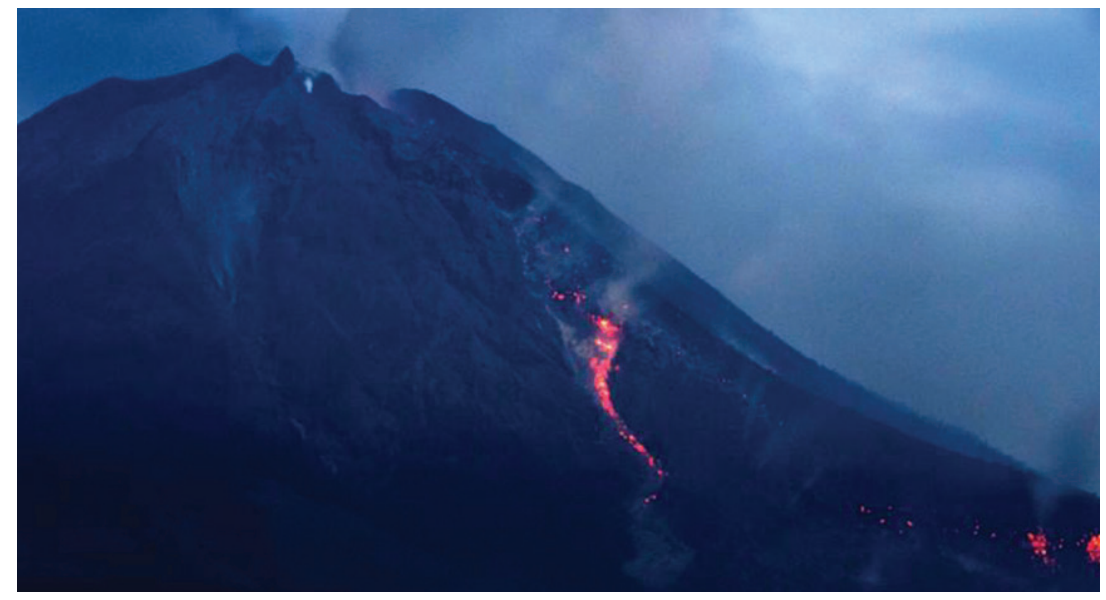

Figure 4. Mount Agung erupted On Saturday 9 March at $12.47 \mathrm{pm}$ Bali local time. The Mountain watcher reported the eruption on Friday (3/15) occurred at 18:27. The ash column height around 1,000 meters above the peak, with eruption duration about 1 minute 23 seconds. ${ }^{10}$

communities who visited Besakih Temple, for pray or doing their service were still allowed to do their activity within the temple area. ${ }^{11}$

\section{MORTUARY OVERLOADED}

Panca Wali Krama started from March 6 to April 12, 2019. During the event, there was an announcement from the PHDI, to ban Ngaben cremation for the deceased until the ritual is over. However, the majority of the people did not comprehend the message well; as a result, mortuaries in several hospitals were reported full due to the late family decided to keep the body until the Panca Wali Krama series at Besakih temple is over. The Chairperson of PHDI Bali Province, I Gusti Ngurah Sudiana, said the overload occurred because the communities misunderstood the announcement. ${ }^{12}$

In Mangusada Hospital, Badung, 116 bodies

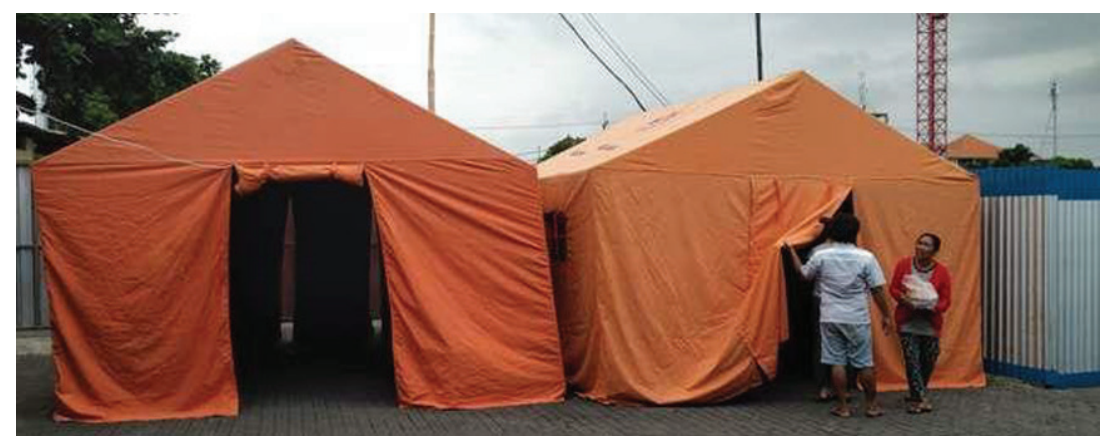

Figure 5 have been deposited in a mortuary while there are more than 20 bodies kept inside a tent due to mortuary overloaded. Mortuary at the Sanglah Central General Hospital reported increased by 50 percent. The total remains deposited in the morgue of Sanglah General Hospital during the Panca Wali Krama reached 106 bodies, and continued to increase every few days. The situation, according to Balinese Hindu believe, is not suitable and considered defiling the area. The dead must be placed on the correct place.

The Main Council of Pakraman Village (MUDP) hastily asked the Hindus family to take the bodies of their relatives from the morgue, to be taken to the cemetery. The bodies that died during the Panca Wali Krama ceremony could be buried or Cremated in ritual Mekingsan ring gni (similar with Ngaben but with different intention). For a commoner, MUDP instructed for the bodies to be buried after sunset While for the priest, it is allowed to be cremated through ritual Mekingsan ring gni. In response, the Governor of Bali, I Wayan Koster, appealed to the family to follow MUDP's instructions. He expressed his support toward MUDP consideration and expecting the information can be carried out as soon as possible by the community, community leaders and other parties. ${ }^{16}$

\section{CONCLUSIONS}

In 2019, a grand Yadnya ceremony, Panca Wali Krama was held two times in Lempuyang Luhur Temple and Besakih Temple. Hindu communities from all regions in Bali came to participate in the event, as their symbol of faith toward the God Almighty. This ten-year event took place for more than twenty days in Lempuyang Luhur and thirtyseven days in Besakih temple. While Panca Wali Krama was taking place at Besakih, Mount Agung has been reported experiencing several hiccups on 9, 15 and 21 March 2019. Despite the eruption, the communities kept doing their prayer and service

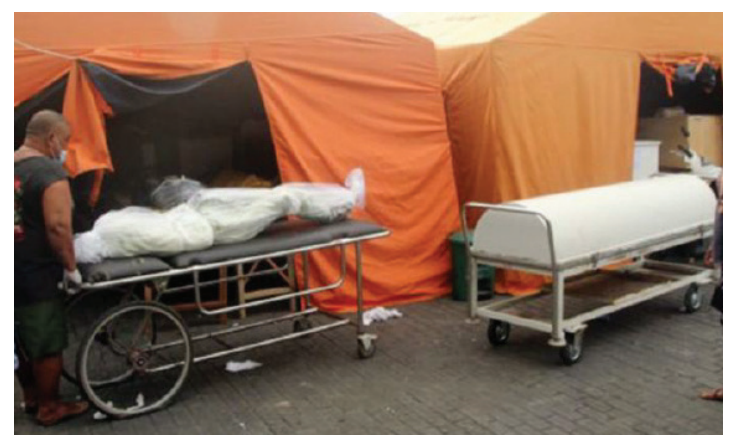

Figure 6

Figure 5 \& 6 In Mangusada Hospital, Badung, 116 bodies have been deposited in a mortuary while there are more than 20 bodies kept inside a tent due to mortuary overloaded 


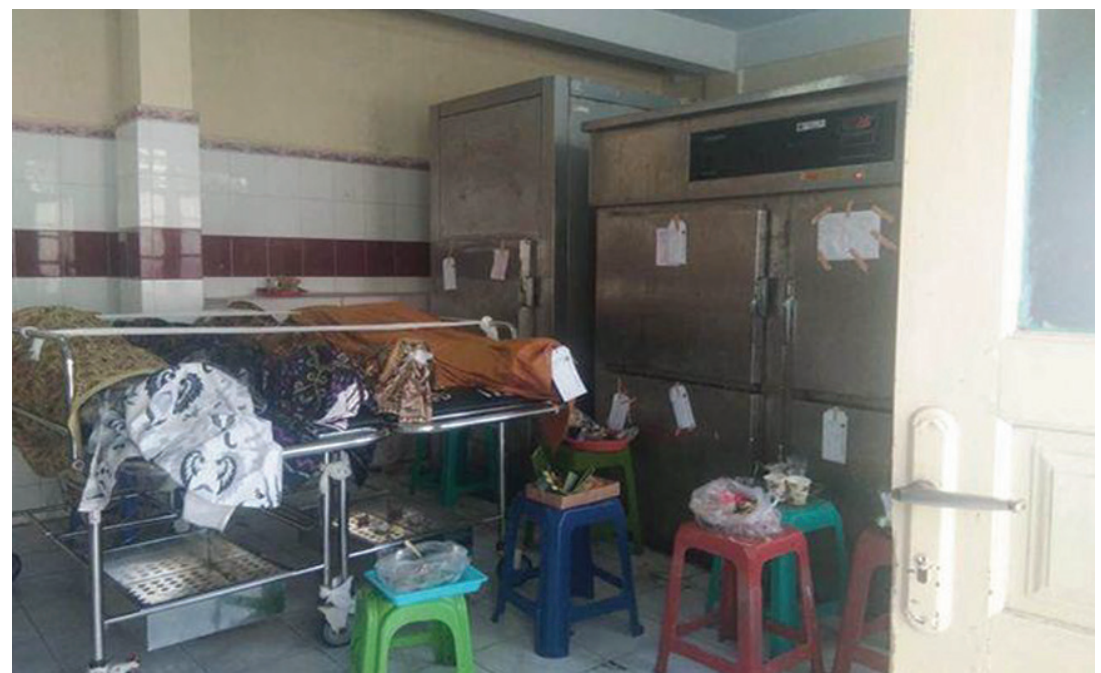

Figure 7. Mortuary overloaded at Tabanan Hospital

at the temple located on the slope of the volcano. Meanwhile, another crisis was faced by hospitals on the island, due to an announcement from the official to ban Ngaben ceremony until the Yadnya is over. As a result, Mortuary in several hospitals was reported overloaded. The official and Government hastily response to the overloaded problem, since according to Balinese Hindu believe, keeping the dead body stranded was considered defiling the area.

\section{REFERENCES:}

1. Anonymous. Panca Wali Krama Pura Lempuyang Kembali Digelar Setelah Ratusan Tahun. Beritabali[dot] com. 2019. Available at URL: https://www.beritabali.com/ $\mathrm{read} / 2019 / 01 / 20 / 201901200006 /$ Panca-Wali-Krama-PuraLempuyang-Kembali-Digelar-Setelah-Ratusan-Tahun. html

2. Anonymous. Panca Wali Krama Pura Lempuyang Sebagai Bentuk Pembersihan Alam Semesta. Beritabali[dot]com. 2019. Available at URL: https://www.beritabali.com/ read/2019/01/20/201901200008/Panca-Wali-Krama-PuraLempuyang-Sebagai-Bentuk-Pembersihan-Alam-Semesta. html

3. David J. Stuart-Fox. Pura Besakih: Pura, Agama dan Masyarakat Bali. Udayana University Press. 2010. ISBN 978-979-3790-36-7. P 308

4. David J. Stuart-Fox. Pura Besakih: Pura, Agama dan Masyarakat Bali. Udayana University Press. 2010. ISBN 978-979-3790-36-7. p 371

5. P Supartika. Berikut Rangkaian Upacara Panca Wali Krama di Pura Besakih, Dimulai 22 Januari Ini. tribun-bali[dot] com. 2019. Available at URL: http://bali.tribunnews. com/2019/01/19/berikut-rangkaian-upacara-panca-walikrama-di-pura-besakih-dimulai-22-januari-ini?page=all .

6. Image taken from Denpasarnow[dot]com. Puluhan Ribu Pengiring Ikuti Upacara Melasti Karya Panca Wali Krama Pura Agung Besakih. 2019. Available at URL: https:// denpasarnow.com/puluhan-ribu-pengiring-ikuti-upacaramelasti-karya-panca-wali-krama-pura-agung-besakih/
7. Image taken from Bagiarta. Tempuh Jarak Belasan Kilometer, Umat Melasti ke Pura Puseh Tebola. Balipost[dot]com. 2019. Available at URL: http://www. balipost.com/news/2019/03/03/70065/Tempuh-JarakBelasan-Kilometer,Umat...html

8. Image taken from Suara[dot] com by F Yusuf. Ritual Melasti Upacara Panca Wali Krama. Antara Foto. 2019. Available at URL: https://www.suara.com/foto/2019/03/03/090000/ ritual-melasti-upacara-panca-wali-krama

9. EM Suputra. Melasti Upacara Panca Wali Krama di Pura Besakih Berlangsung Tiga Hari, Tempuh Perjalanan 64,3 Km. tribun-bali[dot]com. 2019. Available at URL: http:// bali.tribunnews.com/2019/03/02/melasti-upacara-pancawali-krama-di-pura-besakih-berlangsung-tiga-haritempuh-perjalanan-643-km?page=all.

10. Image taken from Dok.TEMPO by W A Prasetyo. PVMBG: Letusan Gunung Agung Dini Hari Terbesar di Awal 2019. Available at URL: https://tekno.tempo.co/read/1192328/ pvmbg-letusan-gunung-agung-dini-hari-terbesar-diawal-2019

11. E Parananda. GUNUNG AGUNG ERUPSI, TAK GANGGU PAMEDEK TANGKIL DI BESAKIH SERANGKAIAN PANCA WALI KRAMA. Balipost[dot] com. 2019. Available at URL: http://www.balipost.com/ news/2019/03/09/70329/Gunung-Agung-Erupsi,TakGanggu ...html

12. I Rosidin. Rumah Sakit di Bali Kelebihan Jenazah Selama Panca Wali Krama, MUDP: Jenazah diletakkan di tenda akibat kesalahpahaman. IDN Times Bali. 2019. Available at URL: https://bali.idntimes.com/news/bali/imamrosidin/ rumah-sakit-di-bali-kelebihan-titipan-jenazah-selamapanca-wali-krama/full

13. Image by IM Darna. RSD Mangusada Masih Simpan 127 Jenazah, Jenazah Titipan Berangsur-angsur Diambil Pihak Keluarga. Bali Tribune. 2019. Available at URL: https:// balitribune.co.id/content/rsd-mangusada-masih-simpan127-jenazah-jenazah-titipan-berangsur-angsur-diambilpihak

14. Image by A Bayu. Kamar Jenazah Overload, RSD Badung Dirikan Tenda Darurat. Bali express. 2019. Available at URL: https://baliexpress.jawapos.com/read/2019/03/05/123300/ kamar-jenazah-overload-rsd-badung-dirikan-tendadarurat

15. Image by Juliadi. Imbauan PHDI Tak Mempan, Jenazah Terus Berdatangan di BRSUD Tabanan. Radar Bali. 2019. Available at URL: https://radarbali.jawapos.com/ $\mathrm{read} / 2019 / 03 / 21 / 126686 /$ imbauan-phdi-tak-mempanjenazah-terus-berdatangan-di-brsud-tabanan

16. Anonymous. Puncak Panca Wali Krama di Pura Besakih, Jenazah Menumpuk di Kamar Mayat, PHDI: Wajib Dikubur, Titip Itu Nista. Radar Bali. 2019. Available at URL: https:// radarbali.jawapos.com/read/2019/03/20/126285/jenazahmenumpuk-di-kamar-mayat-phdi-wajib-dikubur-titipitu-nista

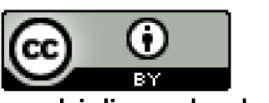

This work is licensed under a Creative Commons Attribution 